\title{
THE ECONOMIC AND FINANCIAL SOURCES OF THE ISIS TERRORIST ORGANIZATION
}

\author{
'B.K.Botakarayev, ${ }^{2}$ M.Zh.Tolegenov, ${ }^{3}$ Y.Benlı
}

\begin{abstract}
While in the past, discussions about war and peace were constantly born in various spheres of society, such as philosophy, humanities, and journalism, today these topics have become one of the most important issues of political science. However, the specific positions and opinions of leading religious experts on this issue were not particularly noted, as they did not contradict the secular point of view.

In the era of globalization, the network of interaction between people and society has become a complex phenomenon. Globalization not only contributes to life in a positive way, but also has a negative impact. Although scientific development, which contributes to positive changes in the world, has entered an effective and rapid process in recent years, the sphere of influence of terrorist organizations is also spreading beyond the borders of the country. Terrorist organizations, on the other hand, use this process to their advantage and threaten the whole world. A terrorist organization called ISIS was able to expand its sphere of influence in a short time, taking advantage of the benefits of globalization.

Although it initially became a specific regional threat, over time it became a threat to the world. For this reason, with the fear that it will negatively affect the world and its future, we have set out to determine the structure, purpose, economic and financial foundations of this organization and the main mechanisms for combating them.
\end{abstract}

Keywords: Radicalism, Caliphate, ISIS, Central Asia, National Security, Peace
${ }^{1-2}$ Khoja Akhmet Yassawi International Kazakh-Turkish University, Turkestan, Kazakhstan

${ }^{3}$ Erciyes University, Kayseri, Turkey

Author-correspondent:

B.K. Botakarayev, bauyrzhan.botakarayev@ayu. edu.kz

Reference to this article:

Botakarayev B.K.,

Tolegenov M.Zh.,

Benli Y. The Economic and

Financial Sources of the Isis

Terrorist Organization //

Adam alemi. - 2021. - No. 3

(89). - P. 122-130.

\section{ИШИМ террорлық ұйымының экономикалық-қаржылық қайнарлары}

\begin{abstract}
Аннотация. Бұрындары соғыс пен бейбітшілік туралы пікірталастар үнемі философия, гуманитарлық ғылымдар, журналистика секілді қоғамның әр салаларында туып жатса, бүгінгі таңда бұл тақырыптар саясаттанудың ең маңызды мәселелерінің біріне айналды. Алайда жетекші дін мамандарының бұл мәселеге қатысты нақты ұстанымы мен пікірлері зайырлылық көзқарасқа қайшы келмегендіктен ерекше аталып көрсетілмеді.

Жаһандану заманында адамдар мен қоғамның өзара әрекеттесу желісі күрделі құбылысқа айналды. Жаһандану өмірге жағымды жағынан үлес қосып қана қоймай, кері әсерін де тигізуде. Әлемдегі оң өзгерістерге үлес қосатын ғылыми даму соңғы жылдары тиімді және жылдам үдеріске енгенімен, террорлық ұйымдардың әсер ету саласы да ел шекарасынан тысқары таралуда. Террорлық ұйымдар болса бұл үдерісті өз пайдасына пайдаланып бүкіл әлемге қауіп төндіруде. ИШИМ деп аталатын лаңкестік ұйым жаһанданудың артықшылықтарын қолдану арқылы қысқа уақыт ішінде өзінің әсер ету аумағын кеңейте алды. Бастапқыда белгілі бір аймақтық қауіпке айналғанымен, уақыт өте келе әлемге қауіп
\end{abstract}


төндірді. Осы себепті біз әлемге және оның болашағына теріс әсер етеді деген қорқынышпен аталмыш ұйымның құрылымын, мақсатын, экономикалық-қаржылық негіздері мен оларға қарсы күресудің негізгі механизмдерін анықтауды мақсат еттік.

Түйін сөздер: Радикализм, халифат, ИШИМ, Орта Азия, ұлттық қауіпсіздік, бейбітшілік

\title{
Экономические и финансовые источники террористической организации ИгИЛ
}

\begin{abstract}
Аннотация. В прошлом дискуссии о войне и мире всегда возникали в различных сферах общества, таких как философия, гуманитарные науки и журналистика, но сегодня эти темы стали одним из самых важных вопросов в политической науке. Однако особые взгляды и мения ведущих религиоведов по этому поводу не акцентировались, так как они не противоречили светской точке зрения.

В эпоху глобализации сеть взаимодействия между людьми и обществом превратилась в сложное явление. Глобализация не только положительно влияет на жизнь, но и оказывет отрицательное влияние. Хотя научное разработки, способствующие позитивным изменениям в мире, были эффективными и быстрыми в последние годы, сфера влияния террористических организаций распространяется за пределы страны. Террористические организации используют этот процесс в своих интересах и угрожают всему миру. Террористическая организация ИГИЛ за короткий период времени смогла расширить сферу своего влияния, воспользовавшись преимуществами глобализации. Изначально это стало региональной угрозой, но со временем стало угрозой для всего мира. По этой причине мы стремились определить структуру, цель, экономические и финансовые рамки организации и основные механизмы борьбы с ними, опасаясь, что это негативно повлияет на мир и его будущее.
\end{abstract}

Ключевые слова: радикализм, халифат, ИГИЛ, Средняя Азия, национальная безопасность, мир.

\section{Introduction}

It is important to note a sharp change in the current situation with the emergence of the manifestation of radicalism in a religious format and its aggressive penetration into various spheres of humanity. The religious nature of jihad, such as the "struggle against one's own lust", began to take on a political format over time. In order for certain organizations and groups to achieve their goals, they began to use religion and religious terminology as masks. In the USSR's war with Afghanistan between 1979 and 1989, in order to resist the occupying Soviet government, many countries went to Afghanistan to lend a helping hand to the Muslim Brotherhood. In order to provide material and logistical support to these volunteers, "Maktab Al Hidama" (service bureau) was established by Osama B. Laden and Abdullah Azzam, a representative of the Palestinian organization "Muslim Brotherhood", whose name was al-Qaeda. Abu Musab al-
Urukawi, a Jordanian who was recognized as the creator of ISIS after the US invasion of Iraq, also began to promote "jihad" in a world format by Osama Bin Laden.

The Republic of Kazakhstan has been at the forefront of the fight against international terrorism for many years. Today, our country is making unprecedented efforts to counter the global terrorist threat. Guided by the resolutions of the UN Security Council and the norms of international law, Kazakhstan promptly responds to the Syrian request for assistance in the fight against ISIS, al-Qaeda, Hezbollah and a number of other terrorist groups. But the most important task on the agenda is to be able to effectively counter the terrorist and extremist ideology in the country, to strike at its propagandists and those who join their ranks, as well as to prevent terrorist attacks that lead to human casualties. Propagandists of this ideology against humanity today are not only ISIS organizations, but also a number 
of organizations recognized as terrorist by the decision of the Supreme Court of the Republic of Kazakhstan. Among them are al-Qaeda, Hizbut-Tahrir al-Islami, Islamic Jihad and others. In this regard, this topic, which is being studied, is currently relevant.

\section{Methodology}

The methodological framework of the study was studied in such diverse fields as Sociology, Political Science, and theology about the nature of non-traditional, destructive religious movements that flowed into countries as a result of the spiritual vacuum created in the geography of Central Asia after the USSR. The importance and scientific novelty of our research also takes into account the historical prerequisites for the emergence of such a terrorist organization as ISIS. In this topic, we will try to show the religious and political basis on which ISIS is based by analyzing it. In general, historical and comparative methods were used in our scientific research.

\section{Main Part}

In the media in many countries of the world, Al-Qaeda and organizations associated with it are evaluated as Sunni. As a specialist in the field of religion, it is necessary to show our opposition to this issue and express our opinion in our own way. First of all, we should not forget that ISIS or an-Nusra organizations in Russia and other countries have common characteristics with these organizations, although they are not related to Al-Qaeda and other organizations. It is surprising that these organizations are openly described in the United States as "Salafi-jihadis" and in Turkey and other countries they are called Sunni. It is known that the foundation of ISIS was laid by Abu Musa al-Zarqawi. Abu Musa, who went to Afghanistan to fight against Soviet troops, was able to establish his own military unit in the camps here, although he did not directly participate in the war. Zarqawi founded the "al-Tawhid ua'l-Jihad Jamaat", which formed the basis of ISIS, with these troops, and later the name of the organization was changed to "Mujahidin Shura Council". With the arrival of the United States in Iraq, Zarqawi established contacts with local Mujahideen in Iraq and actively participated in the antiUS movement. During this period, the main goal of the organization was to destroy the United States and Western countries and create an Islamic caliphate. In 2004, the organization entered into close relations with Al-Qaeda. Understanding this rapprochement is important in terms of understanding and knowing the power of ISIS in Iraq today [1, p. 35].

ISIS does not need large-scale financial support from abroad, such as Al-Qayda and Jabhat an-Nusra. However, they receive assistance from the Sunni states of the Persian Gulf. Nusra. However, they receive assistance from the Sunni states of the Persian Gulf. This Caliphate-State, built from the inside out, has switched to self-financing: it earns billions of dollars by robbing banks, confiscating the property of those who do not support its worldview, exchanging prisoners for a certain fee, selling slaves, smuggling drugs and controlling illegal oil channels. During the peak period of ISIS, about 2.3 billion was lost. it was the richest terrorist organization with a dollar budget. The leadership of the caliphate concluded that financing social programs for the population can be a more effective means of ensuring loyalty and support than mass murder.

American political expert George Perry said that the financial resource will allow the militants to copy the strategy of Hamas, that is, to provide public services to the population, restore the work of hospitals and schools, thereby taking root in the region and gaining the support of the population [2]. ISIS is a new type of terrorist 
organization in which financial support plays a crucial role. The ISIS budget is designed for training militants, equipment, communication facilities, weapons, ammunition, material support of militants, as well as maintaining infrastructure, social sphere in balance, salaries of their elected officials, technical and engineering work. For example, jihadists participating in combat operations receive 500 US dollars a month. The possibility of such income arouses the interest of citizens abroad. In short, the financial and economic resources of ISIS will be used to strengthen the military potential of the "caliphate".

The number of artillery and mortar systems, as well as tanks, is quite large. They use American Abrams tanks, state-of-theart military equipment that allows them to conduct offensive operations at night (night vision goggles, thermocouples) and much more. During the battles near Palmyra, American anti-tank guided missile systems were actively used against Syrian tanks. The practice of blowing up fortified areas of the Syrian army with the help of trucks led by suicide bombers, including those from Russia and other CIS countries, was also widespread [3, p. 54].

\section{ISIS sources of income}

As for budget revenues, first of all, the socalled "tax" is a source of profit. A reflection of the financial independence of the "new state structure" of the ISIS leadership. This organization has a financial Council that oversees the distribution of the Caliphate's finances and checks the activities of the regional governors. The system of sources of replenishment of funds is well thought out, adjusted and strictly controlled by the repressive apparatus of jihadists. These kinds of incomes can be divided into four groups:

1. Income received from oil refining countries;

2. "Taxes" imposed by ISIS on the territories of Syria and Iraq, which are under its control;

3. Income from confiscation of financial and material assets and illegal entrepreneurship (drugs, jewelry, gold, etc.);

4. Foreign financial assistance received from legal entities and individuals through various channels.

ISIS has seized phosphate ores near Palmyra in Syria and at the AL-Qaima plant in Iraq. The organization also manages enterprises for the production of sulfur, phosphoric acid, salt in Iraq and Syria, as well as a number of large cement plants. Despite this,Despite this, the main goal of ISIS in the industrial sphere is considered to be the oil production and manufacturing industry, which, according to the plan of the jihadists, is designed to provide a high and stable level of income for its regime. The main part of them is made up of funds from the sale of oil from fields controlled by terrorists. Their number has been steadily increasing since the day ISIS manifested itself [4, p. 27]. ISIS had already launched its oil strategy in 2014 before the invasion in Iraq. In 2013, at a time when oil prices were low, the terrorists who appeared in Syria formed the financial and economic basis of the future "caliphate" of oil resources.In addition to the capture of Mosul in the summer of 2014, ISIS's thick arm has already taken control of oil resources in Kirkuk province, located in northeastern Iraq. It was after this that the militants began to establish patrols in the fields and attract oil specialists to continue oil production and supply to the market.

The Iraqi army successfully appropriated about 450 million from the exploitation of the fields before liberating this oilproducing area in April 2015. According to the Iraqi Ministry of oil, ISIS militants were expelled from Salah al-Din province, It has lost weight in almost all of the previously captured fields in Iraq. At the end of 2015, they operated only three oil wells in the province of Nainaua. The bulk of the oil produced by ISIS is concentrated in eastern 
Syria, which is rich in these resources.

The second most important source of income for the ISIS organization is numerous taxes and payments. At the same time, this organization reproduces the system of budget processes carried out in state structures. Such tax revenues, of course, have their own peculiarities and cannot be considered legal. The nature of these receipts and their approximate amount are carried out in the following areas:

1. Entrepreneurs are charged a tax of $10 \%$ on income and capital, $2 \%$ on purchases;

2. Tax collectors may, at their discretion, tax large and high-quality housing or a new car at an indefinite rate;

3. When crossing the border, you must pay customs fees;

4. ISIS receives transport payments for transit for all goods that have passed through its territory. In northern Iraq, it was necessary to pay 200 US dollars for the passage of one truck, and 500 US dollars for a tanker with fuel as a "road tax". In case of entry into Iraq through the border between Syria and Jordan, it was obliged to pay a "customs tax" of 800 US dollars.

5. Road tax collectors not only provide drivers with receipts for payment, but also provide them with fake receipts for passing through Iraqi official customs, which are accepted at government checkpoints;

6. ISIS forces depositors in private banks to pay a $5 \%$ tax on cash withdrawals. According to the "protection agreement" for non-Sunnis, an adult is paid about 720 US dollars per person per year. And if this person is engaged in entrepreneurship, he will pay a triple amount of this amount;

7. Another financial income is a one time payment for "repentance". The people of the territories captured by ISIS are forced to swear allegiance to the "caliphate", apologizing for their sins in the past. This applies primarily to former military, police, government, education workers, as well as members of other anti-ISIS groups. These people pay a very large amount and receive a "document of repentance", such as an identity card, which is issued to citizens of the "new state". To extend this" document", you must also pay additional fees. This procedure will help former civil servants to avoid persecution and punishment by the newly emerging authorities, to get a job in the ISIS administration or in educational institutions in the occupied territories [5, pp. 26-28]. The third source of income of the organization is entrepreneurial income, which the organization does not hide in the world. We are talking about the exchange of banks, real estate, goods, and captured people for money in the countries occupied by the organization by entrepreneurs. In particular, in June 2014, militants of the group looted a branch of the Central Bank of Iraq located in Mosul and, according to sources, seized from 900 million to 2 billion US dollars. Homes abandoned by refugees, shops that have lost their owners will be rented out and will bring ISIS 3 million US dollars in revenue in the form of monthly rent payments. In agricultural production, the Islamic State will establish control over grain storage facilities and seize agricultural machinery from farmers for subsequent rental to their owners. Stolen grain is used not only to make a profit and control the regional grain market, but also as a means of influencing food security in this region of the Middle East. The same roads are used for Water Resources. Grain is delivered from Iraq to Syria and Turkey.

\section{Historical monuments and the condition of man}

In addition, smuggling of monuments is considered a serious criminal business. ISIS benefits from this in two ways: by selling historical monuments and receiving a certain amount of fees from people who transport antiquities through the occupied 
territory. ISIS and other criminal groups in Syria currently earn tens of millions of US dollars from the sale of historical and cultural relics stolen from Syria. The Islamic State has more than 4,500 archaeological sites, some of which have already been included in the UNESCO World Heritage List. $90 \%$ of the country's cultural monuments are located in war-torn regions, which, in turn, created favorable conditions for large-scale theft [6, p. 22].

Another source of income is human trafficking. ISIS also sells people for ransom at "slave auctions". According to the group for the development of financial measures to combat money laundering (English - Financial Action Task Force on Money launching - FATF), the profit from criminal activities amounted from 20 to 45 million dollars [6, p. 24].

It also receives income from the flow of refugees sent to Europe: terrorists collect payments from refugees for illegal transportation to the countries of the euro Union. At the end of 2015, it earned more than 300 million US dollars thanks to the refugee channel. In 2014-2015, the conquered regions provided ISIS with the main part of its financial resources. In addition, direct transfers from abroad also served as a kind of financial reserve.

First of all, financial transfers from various funds, including donations from special services of countries such as Qatar, Saudi Arabia, Turkey and other government agencies, are made anonymously. These funds are spent not only on the purchase of weapons. Turkey pays for treatment and rest in its military hospitals for ISIS fighters from Syria. On the territory of Turkey there are bases for military training of militants. The second is taxes, which are constantly formed in religion, that is, donations from Muslims. These funds will be used to collect donations, distribute them for the needs of the poor, and spread the worldview of "pure Islam" around the world. According to available data, ISIS has earned about 400 million rubles through this channel only from Russia.

Social media is considered the third source of fundraising. Modern banking technologies make money transfers easier. The so-called crowdfunding service, as a transfer of public donations, contributes to significant fundraising, while maintaining anonymity. There is also a Muslim money transfer system called "Hauala". For example, if a citizen in the United States wants to transfer funds to the needs of jihadists in the second part of the world, he calls another person through an intermediary on the phone and transfers the amount without a document and confirmation, and he, in turn, sends it to the next intermediary. In this way, the money will be transferred to the designated place and it will be impossible to control these transactions. Some of the money comes from militants who have arrived in areas controlled by the Islamic State.

The fourth source of income is income from legal financial activities and entrepreneurship. An additional "advantage" of Islamic banks is the experience of combining and coordinating the funds of various depositors in the formation of investment paths in certain projects.

It is difficult to imagine the long-term economic viability of the "Islamic State" created by ISIS and the economic revival of the occupied regions. The organization's economic agenda seems vague. Obviously, ISIS cannot give up the above source of income.

Despite the fact that the abovementioned sources of income of ISIS generate millions of dollars in revenue, its financial situation cannot be called stable. The amount of revenue provided by terrorist activities in Syria and Iraq is directly proportional to the size of the regions controlled by the organization. That is, the smaller the controlled zones, the smaller the criminal income. Therefore, it is clear that the most effective way to 
destroy the financial and economic basis of the "caliphate" is to liberate these regions and restore legitimate power here.

Based on the above analysis, we can conclude that the organization "Islamic State" in international relations has been actively studied in domestic and Western science from the moment of its emergence to the present day. "What is the ultimate goal of ISIS?" and "what steps are they willing to take to achieve their goals?" and also "who is behind ISIS"? there are many points of view as an answer to the main questions. In general, whatever forces are behind the group, everything that this organization has done has dealt a heavy blow to Islam and Muslims.

Despite its short history, ISIS, which is not officially registered as a state, has become an issue on the agenda not only of the Middle East, but also of many countries on the planet Earth. A number of factors of a historical, political, religious, social, ethnic, geographical and economic nature have been identified that exacerbate modern international relations. It should also be noted that ISIS is now considered the richest terrorist organization in the world. Al-Qaeda and other well-known organizations that have been stirring on the world stage for more than a decade did not have such a complex system [7].

\section{ISIS has a complex structure}

The conflict in the Middle East with the participation of ISIS and world countries was actively going on. So far, there have been many attempts to destroy ISIS. However, they were limited only to weakening this organization. Although ISIS emerged as a local organization, it has become a global terrorist organization day by day. The social structure that makes up the organization gradually differentiated and acquired a complex structure. ISIS, which differs from other organizations in its unique structure and worldview, has made it somewhat difficult for specialists to understand. Therefore, it has become a global threat, which has made it difficult to fight it. The socio-political environment, ideological infrastructure, territory, international relations, economic resources, methods of communication and propaganda in the creation of ISIS were most different from other groups of terrorists.

Experts agree unanimously that the organization has carefully studied the social structure and every person who speaks to the audience, taking into account the methods and arguments used to lure people. To deal with an organization that has such a complex structure and can develop effective strategies, we need to analyze and study the methods used by it. The methods and actions of ISIS, which differ from other terrorist organizations in the region and in the world, and which they carry out in different regions around the world, can be seen that the organization is well organized on a global scale.

Taking measures to reduce and stop ISIS activity in the region should not be limited to countries in this territory. Since this organization is not a specific territorial organization, but a world-class terrorist organization, it is necessary to form an international coalition. Within the framework of the agreement to be implemented, economic routes such as oil trade and drug sales, which constitute the financial resources of the organization, should be cut off. In order to undermine the power of social media, which is used not only by ISIS, but also by other terrorist organizations that skillfully use the internet to spread their ideology, international companies that dominate social networks also need to work with the agreement. Social media accounts and sites opened by ISIS should be closed, the place of people who open these accounts and sites should be determined, and the necessary legal measures should be taken.

For young people who make up the main 
target audience of ISIS, it is necessary to organize awareness-raising campaigns and take measures to prevent their radicalization. From this point of view, an effective tool that is most used by young people can be used in an interactive environment.

\section{Conclusion}

As you know, the destructive activity of international terrorist organizations, primarily the widespread spread of the Daish terrorist group, is recognized as one of the main threats to world security. If we analyze the above data, it shows that people who were brought up on the path of "family-kindergar ten-schooluniversity" began to go to terrorists. Experts recommend starting work with children at the age of five. In this way, communication with terrorists is like talking to a "stranger" on the street. As for schoolchildren and students, the future of the country will be realized only through the deregulation of existing psychological support services, and not through controls and prohibitions.

Today, effective counteraction to the propaganda of ISIS and other similar terrorist organizations requires the consolidation of efforts of states and the organization of close cooperation between their law enforcement agencies.

In order to compress the air of the economic and financial foundations of ISIS, it is necessary to establish strict control over the reception of documents of antiques in the world markets of ancient exhibits. It is also necessary to supplement international restrictive measures by stopping trade in this area with Iraq and Syria. After all, weakening the financial and material base of the organization means damaging the economy of the "caliphate". If we damage the economy today, ISIS militants will lose their source of income and may rebel in the caliphate tomorrow.

Despite the fact that the ISIS organization is not active at the moment, the Taliban extremist organization, which has one worldview and vision, one slogan and one goal, is becoming an urgent issue on the agenda. "Tell me who your friend is, I'll tell you who you are," the Taliban seems to be a continuation of ISIS. It is the same with the current Taliban movement, such as the establishment of a caliphate by ISIS, the issue of marriage within the family, the destruction of the role of women in society, and the support of the law, which is convenient for them by denying the rule of law in countries. It is true that if we recognize the worldview, views and interests of any movement, such as ISIS, we will resist the coming trends.

\section{References}

1 Chambers P. Abu Musab Al Zarqawi: The Making and Unmaking of an American Monster (in Baghdad) // Alternatives: Global, Local Political. - 2012. - 37 (1).

2 AFP; Le Parisian. 18.06.2014.

3 «Исламское государство»: сущность и противостояние. Аналитический доклад / Под общей ред. Я.А.Амалиной и А.Г.Арешева. - Владикавказ: Кавказский геополитический клуб. - 2015. - 226 с.

4 Крук А. Нельзя понять, что такое ИГИЛ, не зная историю Ваххабизма в Саудовской Аравии // Ислам в современном мире. 2014. №3. - С. 20-27.

5 «Исламское государство»: Феномен, эволюция, перспективы // Институт международных исследований (ИМИ) Аналитические доклады 2016. - №1 (45). - 43 с.

6 Финансирование террористической организации «Исламское государство Ирака и Леванта» (ИГИЛ). Отчет ФАТФ. Февраль 2015. - 64 c.

7 Икрам Собиров «Что объединило исламистов и арт-дилеров?». - Столетие. - 1.06.2015. http://www.stoletie.ru/fakty_i_ kommentarii/chto_objedinilo_islamistov_i_ artdilerov_934.htm. 19.08.2021

\section{Transliteration}

1 Chambers P. Abu Musab Al Zarqawi: The Making and Unmaking of an American Monster (in Baghdad) // Alternatives: Global, Local 
Political. - 2012. - 37 (1). (in Eng)

2 AFP; Le Parisian. 18.06.2014. (in Eng)

3 «Islamskoe gosudarstvo»: sushhnost' i protivostojanie. Analiticheskij doklad ["Islamic State": essence and opposition. Analytical report] / Pod obshhej red. Ja.A.Amalinoj i A.G.Aresheva. - Vladikavkaz: Kavkazskij geopoliticheskij klub. - 2015. - 226 s. (in Russ)

4 Kruk A. Nel'zja ponjat', chto takoe IGIL, ne znaja istoriju Vahhabizma v Saudovskoj Aravii [It is impossible to understand what ISIS is without knowing the history of Wahhabism in Saudi Arabia] // Islam v sovremennom mire. 2014. №3. - S. 20-27. (in Russ)

5 «lslamskoe gosudarstvo»: Fenomen, jevoljucija, perspektivy [Islamic State: Phenomenon, Evolution, Perspectives] // Institut mezhdunarodnyh issledovanij (IMI) Analiticheskie doklady 2016. - №1 (45). - 43 s. (in Russ)

6 Finansirovanie terroristicheskoj organizacii «Islamskoe gosudarstvo Iraka i Levanta» (IGIL). [Financing of the terrorist organization Islamic State of Iraq and the Levant (ISIS)] Otchet FATF. Fevral' 2015. - 64 s. (in Russ)

7 Ikram Sobirov «Chto ob'edinilo islamistov i art-dilerov?». - Stoletie. - 1.06.2015. http:// www.stoletie.ru/fakty_i_kommentarii/chto_ objedinilo_islamistov_i_artdilerov_934.htm 19.08.2021 (in Russ).

\section{INFORMATION ABOUT AUTHORS}

Bauyrzhan Botakarayev

Mukhit Tolegenov

Yusuf Benlı

Бауыржан Куанышбаевич Ботакараев

Мұхит Жылқайдарұлы Төлегенов

Юсуф Бенли

Бауыржан Куанышбаевич Ботакараев

Мұхит Жылқайдарұлы Төлегенов

Юсуф Бенли
PhD, Senior Lecturer, Khoja Akhmet Yassawi International Kazakh-Turkish University, Turkestan, Kazakhstan. ORCID ID: 0000-0002-8164-8049, bauyrzhan.botakarayev@ayu.edu.kz

PhD, Senior Lecturer, Khoja Akhmet Yassawi International Kazakh-Turkish University, Turkestan, Kazakhstan. mukhit.tolegenov@ayu.edu.kz

Prof. Dr. Erciyes University, Kayseri, Turkey, ybenli@ erciyes.edu.tr

PhD, аға оқытушы, А.Ясауи атындағы Халықаралық қазақ-түрік университеті, Түркістан, Қазақстан. ORCID ID: 0000-0002-81648049, bauyrzhan.botakarayev@ayu.edu.kz

PhD, аға оқытушы, A. Ясауи атындағы Халықаралық қазақ-түрік университеті, Түркістан, Қазақстан, mukhit.tolegenov@ayu.edu.kz

Др., Проф. Эрджиес университеті, Кайсери, Түркия Республикасы, ybenli@erciyes.edu.tr

$\mathrm{PhD}$, старший преподаватель, Международный казахско-турецкий университет им. А.Ясави, Туркестан, Казахстан. ORCID ID: 0000-00028164-8049, bauyrzhan.botakarayev@ayu.edu.kz

$\mathrm{PhD}$, старший преподаватель, Международный казахско-турецкий университет им. А.Ясави, Туркестан, Казахстан. mukhit.tolegenov@ayu. edu.kz

Др., Проф. Университет Эрджиес, Кайсери, Республика Турция, ybenli@erciyes.edu.tr 